\title{
Characterisation of Staphylococcus aureus isolated from meat processing plants - a preliminary study
}

\author{
Magdalena Kizerwetter-Świda ${ }^{1}$, Dorota Chrobak-Chmiel ${ }^{1}$, Magdalena Rzewuska ${ }^{1}$, \\ Joanna Pławińska-Czarnak ${ }^{2}$, Marian Binek ${ }^{1}$ \\ ${ }^{1}$ Department of Preclinical Sciences, Faculty of Veterinary Medicine, \\ Warsaw University of Life Sciences-SGGW, 02-786 Warsaw, Poland \\ ${ }^{2}$ Department of Food Hygiene and Public Health, Faculty of Veterinary Medicine, \\ Warsaw University of Life Sciences-SGGW, 02-776 Warsaw, Poland \\ magdalena_kizerwetter_swida@sggw.pl
}

Received: July 21, 2016

Accepted: November 16, 2016

\begin{abstract}
Introduction: Livestock-associated methicillin-resistant Staphylococcus aureus (LA-MRSA) belonging to the clonal complex 398 (CC398) emerged recently in livestock as a new type of MRSA, which may cause zoonotic infections. This study presents data on the characterisation of $S$. aureus isolated from the meat processing plants. Material and Methods: $S$. aureus was isolated from 90 samples collected in the raw meat warehouse, from devices and surfaces of meat processing plants, and from finished meat products. The isolates were subjected to molecular analysis in order to investigate the presence of enterotoxin genes, the mecA gene, and to verify whether they belong to the clonal complex 398. The genetic relatedness of the isolates was determined using pulsed-field electrophoresis. Likewise, antimicrobial susceptibility was tested. Results: From 21 S. aureus strains isolated, five belonged to the CC398, two of which were recognised as MRSA and three as methicillin-sensitive Staphylococcus aureus (MSSA). The most prevalent enterotoxin genes were seg and sei. Two MRSA CC398 isolates, three MSSA CC398, and one MSSA were classified as multidrug-resistant. Conclusion: The first isolation of MSSA CC398 from beef in Poland indicates contamination of beef by strains belonging to this clonal complex. The occurrence of multidrug-resistant enterotoxigenic $S$. aureus isolates in the finished meat products constitutes a potential risk for the consumers.
\end{abstract}

Keywords: meat, Staphylococcus aureus, clonal complex 398, antibiotic resistance.

\section{Introduction}

Staphylococcus aureus is considered as one of the most important pathogenic bacteria due to its ability to cause food-borne diseases and various types of infections. The methicillin-resistant $S$. aureus (MRSA) is of particular importance. Traditionally, two groups are distinguished among its strains: hospital-acquired MRSA (HA-MRSA) and community-acquired MRSA (CA-MRSA) (8, 13). Recently, a new type of isolates emerged into the $S$. aureus population, belonging to the clonal complex 398 (CC398) and defined as livestockassociated MRSA (LA-MRSA) (5, 29). Initially S. aureus CC398 was found to predominate among MRSA in pigs in Europe, but it may also colonise calves, cows, sheep, and poultry $(11,31)$. Transmission of LA-MRSA occurs especially in humans with occupational exposure to livestock, particularly pig farming (13). It is also likely that LA-MRSA may be acquired through contaminated meat products $(8,31)$. These strains may cause similar infections in humans as S. aureus or MRSA (27), although most of the virulence factors typical for $S$. aureus are not detected among isolates of the clonal complex 398 (12). However, the recent reports indicate the presence of enterotoxin genes in these strains (4). Given the changing epidemiology, updated information on $S$. aureus strains is needed for the proper control measures of this pathogen $(5,29)$.

The aim of this study was preliminary characterisation of $S$. aureus occurring in the meat processing plants. The $S$. aureus isolates were subjected to molecular analysis in order to investigate the presence of enterotoxin genes, the mecA gene, and 
to verify whether they belong to the CC398. Additionally, antimicrobial susceptibility of the isolates was tested.

\section{Material and Methods}

Isolation and identification of $\boldsymbol{S}$. aureus. A total number of 90 samples were obtained from three different meat processing plants from the area of Warsaw; 30 samples from each plant. From each plant, 10 samples were collected in the raw meat warehouse, 10 samples from the devices and surfaces, and 10 from the finished meat products. Staphylococci were isolated using a modified method with enrichment culture in Mueller-Hinton broth, as the objective of the study was not to determine the microbiological quality of samples, but to isolate $S$. aureus. The samples were taken by vigorous swabbing of the surface with sterile swab moistened with saline. Each swab was put in $10 \mathrm{~mL}$ of Mueller-Hinton broth (bioMérieux, France), containing $6.5 \% \mathrm{NaCl}$, and incubated at $37^{\circ} \mathrm{C}$ for $24 \mathrm{~h}$. The $10 \mu \mathrm{L}$ of this culture was inoculated on Columbia agar with 5\% sheep blood (bioMérieux, France). Colonies formed after incubation were evaluated on the basis of colony morphology and haemolytic activity. All isolates producing colonies characteristic for $S$. aureus were tested with a tube test for coagulase and catalase production according to standard procedures. SlidexStaph test (bioMérieux, France) was used for initial identification of $S$. aureus isolates.

Preparation of bacterial DNA. A single colony of pure culture of each isolate was transferred to $25 \mu \mathrm{L}$ of lysostaphin (100 mg/mL, A\&A Biotechnology, Poland) and incubated at $37^{\circ} \mathrm{C}$ for $10 \mathrm{~min}$. Next $25 \mu \mathrm{L}$ of proteinase K $(20 \mathrm{mg} / \mathrm{mL}$, A\&A Biotechnology, Poland) and $75 \mu \mathrm{L}$ of Tris- $\mathrm{HCl}$ buffer were added to the bacterial suspension, which was incubated at $37^{\circ} \mathrm{C}$ for $10 \mathrm{~min}$. The mixture was centrifuged for $5 \mathrm{~min}$ at $15,000 \mathrm{rpm}$, and the resulting supernatant containing the isolated DNA was used as a template in PCR reactions.

Detection of $S$. aureus-specific fragment of nuc gene, mecA gene, clonal complex 398, and enterotoxin genes. $S$. aureus was identified based on the amplification of the nuc gene described by Sasaki et al. (26). All obtained isolates were screened by duplex PCR using primers specific for mecA gene and clonal complex 398 (28). Strain MRSA CC398 S0358, kindly provided by the University of Copenhagen, Faculty of Health and Medical Sciences, Department of Veterinary Disease and Biology, served as a positive control (14). The detection of enterotoxin genes sea, seb, sec, sed, and see was performed by the method described by Becker et al. (2). Additionally, multiplex PCR was used for amplification of sei, sej, sel, and sem genes (7). PCR reactions were conducted using Dream $\mathrm{Taq}^{\mathrm{TM}}$ Master Mix (2x) (Thermo Scientific, USA) according to the manufacturer's instructions. All amplified products $(10 \mu \mathrm{L})$ were resolved on $1.5 \%$ agarose gel stained with ethidium bromide and documented with Versa Doc Model 1000 Imaging System with Quantity One 4.4.0 software (BioRad Laboratories, USA).

Pulsed-field gel electrophoresis (PFGE). PFGE was performed according to the harmonised protocol for $S$. aureus (23) with minor modifications (18). The restriction fragments obtained by digestion of staphylococcal DNA with SmaI $(20 \mathrm{U} / \mu \mathrm{L}$, Thermo Scientific, USA) were separated using a CHEF-DR II System (BioRad Laboratories, USA). Gel images were analysed by Gel Compare II version 4.6 (Applied Maths, Belgium) and cluster analysis was performed by UPGMA using dice similarity coefficient with optimisation set at $0.5 \%$ and position tolerance at $1.5 \%$. The isolates were clustered using an $80 \%$ homology cut-off, above which the isolates were considered to be closely related and assigned to the same PFGE cluster (30).

Antimicrobial susceptibility testing. All $S$. aureus isolates were evaluated for their antimicrobial susceptibility by disk diffusion method according to the EUCAST guidelines (10). The following antimicrobials were tested: amoxicillin (AMX, $25 \mu \mathrm{g}$ ), cefoxitin (FOX, $30 \mu \mathrm{g}$ ), gentamicin (GEN, $10 \mu \mathrm{g}$ ), erythromycin (ERY, $15 \mu \mathrm{g}$ ), clindamycin (CLI, $2 \mu \mathrm{g}$ ), ciprofloxacin (CIP, $5 \mu \mathrm{g}$ ), tetracycline (TET, $30 \mu \mathrm{g}$ ), and trimethoprim/sulfamethoxazole (SXT, 1.25/23.75 $\mu \mathrm{g}$ ).

\section{Results}

In total, $21(23.2 \%)$ out of 90 samples were positive for $S$. aureus. The majority of the isolates were recovered from pork in the raw meat warehouse. The details concerning the place of isolation and type of meat are shown in Table 1.

Five out of 21 obtained isolates were assigned to the CC398 (Table 2). Three of them originated from finished meat products and two from raw poultry meat before processing. Moreover, two of the five $S$. aureus CC398 isolates were recognised as MRSA, one from finished pork product, and one from raw turkey meat. The most prevalent enterotoxin genes were seg and sei identified in five MSSA (methicillin-sensitive S. aureus) isolates, one MRSA CC398, and one MSSA CC398 that was also positive for sea gene. Additionally, one MSSA isolated from the knife used during meat processing was positive for enterotoxin B gene. All isolates were negative for sec, sed, see, sel, and sem enterotoxin genes.

Twelve distinct PFGE profiles were observed among $16 \mathrm{~S}$. aureus isolates (Fig. 1). The remaining five isolates belonging to the CC398 were nontypeable by PFGE using SmaI. All PFGE profiles showed relatively high level of similarity. Some strains originated from the same plants and the same type of meat showed $100 \%$ identity in Gel Compare analysis of 
PFGE profiles. Additionally, one isolate (6/04) from beef and one from pork $(5 / 04)$ in the same plant exhibited identical PFGE profiles.

The antimicrobial resistance patterns of examined isolates are presented in Table 2. In general, $28.6 \%$ of $S$. aureus isolates were susceptible to all antimicrobials tested, and $33.3 \%$ showed only amoxicillin resistance. Two out of three MSSA CC398, two MRSA CC398, and one MSSA isolates exhibited multidrug resistance phenotype with resistance to three or more classes of antimicrobial agents.

Table 1. The number of $S$. aureus isolates and the place of isolation in the meat processing plants

\begin{tabular}{llll}
\hline \multirow{2}{*}{ Place of isolation } & \multicolumn{3}{l}{ Type of meat - number of $S$. aureus isolates } \\
\cline { 2 - 4 } & Pork & Beef & Poultry \\
\hline Raw meat warehouse & 8 & 2 & 3 (2 turkeys, 1 chicken) \\
Finished meat products & 2 & 3 & 2 (1 turkey, 1 guinea fowl $)$ \\
Knife surface used in the meat processing plant & 1 & 0 & 0 \\
\hline
\end{tabular}

Table 2. Characteristics of $S$. aureus isolates from meat processing plants

\begin{tabular}{|c|c|c|c|c|c|c|}
\hline $\begin{array}{l}\text { Meat processing } \\
\text { plant }\end{array}$ & Source & Isolate & MSSA/MRSA & CC398 & $\begin{array}{l}\text { Presence of enterotoxin } \\
\text { genes }\end{array}$ & Resistance pattern \\
\hline A & pork - $\mathrm{R}^{\mathrm{a}}$ & $1 / 04$ & MSSA & - & - & - \\
\hline A & pork - R & $2 / 04$ & MSSA & - & seg, sei & GEN \\
\hline A & pork - R & $3 / 04$ & MSSA & - & seg, sei & - \\
\hline A & pork - R & $5 / 04$ & MSSA & - & seg, sei & AMX \\
\hline A & beef - R & $6 / 04$ & MSSA & - & seg, sei & AMX \\
\hline A & beef - R & $8 / 04$ & MSSA & - & seg, sei & AMX, GEN, TET \\
\hline A & pork - $\mathrm{FP}^{\mathrm{b}}$ & $23 / 04$ & MRSA & + & $s e g, s e i$ & $\begin{array}{l}\text { AMX, FOX, SXT, GEN, ERY, } \\
\text { CLI, TET }\end{array}$ \\
\hline A & beef - FP & $29 / 04$ & MSSA & - & - & AMX, GEN \\
\hline A & beef - FP & $30 / 04$ & MSSA & - & - & - \\
\hline $\mathrm{B}$ & chicken - R & $11 / 05$ & MSSA & - & - & AMX \\
\hline B & turkey - R & $14 / 05$ & MSSA & + & sea, seg, sei & AMX, GEN, ERY, CLI, TET, CIP \\
\hline $\mathrm{B}$ & turkey - R & $15 / 05$ & MRSA & + & - & $\begin{array}{l}\text { AMX, FOX, SXT, GEN, ERY, } \\
\text { CLI, TET }\end{array}$ \\
\hline $\mathrm{B}$ & guinea fowl - FP & $20 / 05$ & MSSA & - & - & - \\
\hline B & turkey FP & $22 / 05$ & MSSA & - & - & - \\
\hline $\mathrm{C}$ & knife $-E^{c}$ & $5 / 06$ & MSSA & - & $s e b$ & GM \\
\hline $\mathrm{C}$ & pork - FP & $11 / 06$ & MSSA & + & - & AMX, GEN, ERY, TET \\
\hline $\mathrm{C}$ & beef - FP & $16 / 06$ & MSSA & + & - & AMX \\
\hline $\mathrm{C}$ & pork - R & $21 / 06$ & MSSA & - & - & AMX \\
\hline $\mathrm{C}$ & pork - R & $22 / 06$ & MSSA & - & - & AMX \\
\hline $\mathrm{C}$ & pork - R & $24 / 06$ & MSSA & - & - & AMX \\
\hline $\mathrm{C}$ & pork - R & $25 / 06$ & MSSA & - & - & - \\
\hline
\end{tabular}

${ }^{\mathrm{a}} \mathrm{R}$ - raw meat; ${ }^{\mathrm{b}} \mathrm{FP}$ - finished product; ${ }^{\mathrm{c}} \mathrm{E}$ - environmental sample; AMX - amoxicillin; FOX - cefoxitin; GEN - gentamicin; TET - tetracycline; SXT - trimethoprim/sulfamethoxazole; ERY - erythromycin; CLI - clindamycin; CIP - ciprofloxacin
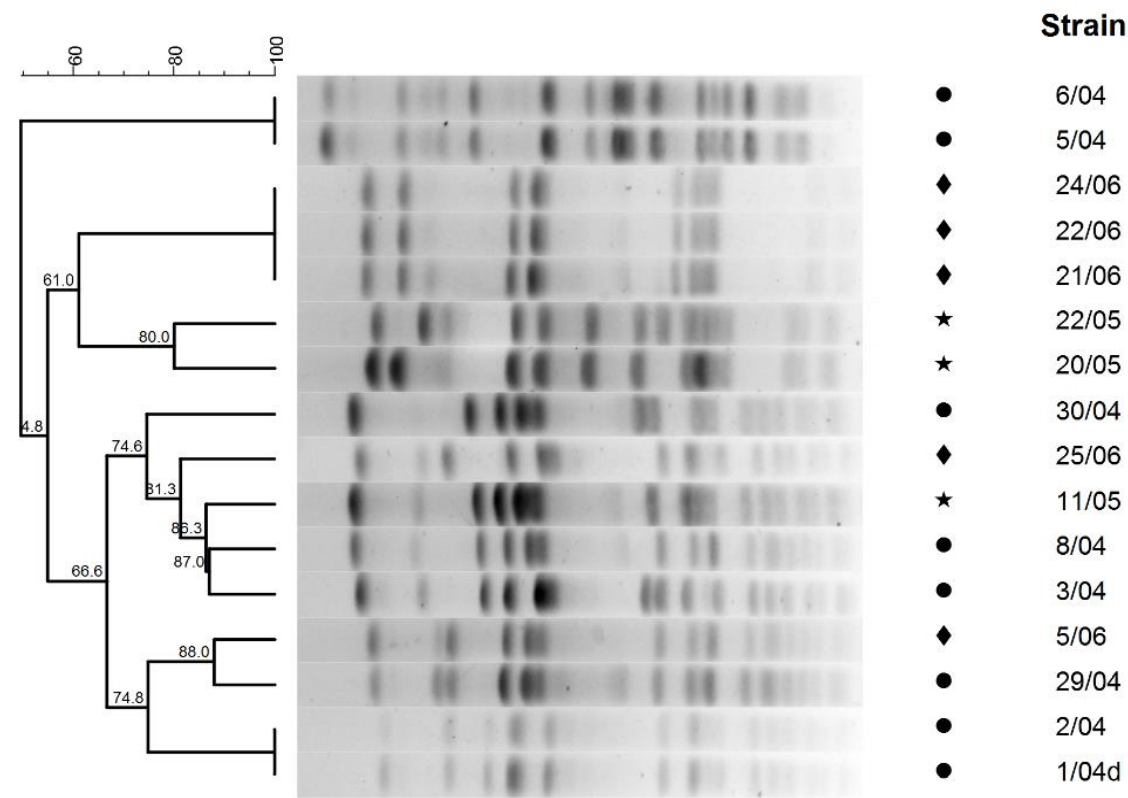

$\begin{array}{ll}\text { Staphylococcus } & \text { aureus } \\ \text { Staphylococcus } & \text { aureus } \\ \text { Staphylococcus } & \text { aureus } \\ \text { Staphylococcus } & \text { aureus } \\ \text { Staphylococcus } & \text { aureus } \\ \text { Staphylococcus } & \text { aureus } \\ \text { Staphylococcus } & \text { aureus } \\ \text { Staphylococcus } & \text { aureus } \\ \text { Staphylococcus } & \text { aureus } \\ \text { Staphylococcus } & \text { aureus } \\ \text { Staphylococcus } & \text { aureus } \\ \text { Staphylococcus } & \text { aureus } \\ \text { Staphylococcus } & \text { aureus } \\ \text { Staphylococcus } & \text { aureus } \\ \text { Staphylococcus } & \text { aureus } \\ \text { Staphylococcus } & \text { aureus }\end{array}$

Fig. 1. Dendrogram showing the level of similarity of SmaI restriction PFGE patterns of the genomic DNA of S. aureus. Different shapes indicate various meat processing plants $(\bullet-$ meat processing plant $\mathrm{A} ; \star$ - meat processing plant $\mathrm{B} ; \bullet-$ meat processing plant $\mathrm{C})$ 


\section{Discussion}

The occurrence of $S$. aureus, in particular MRSA and enterotoxigenic strains in foods of animal origin, represents a relevant issue with regard to food safety $(8$, 15). The presence of LA-MRSA in raw meat was described in different countries. In the Netherlands MRSA (mostly the CC398) was detected in $10.7 \%$ of pork samples, $15.2 \%$ of beef, and $35.3 \%$ of turkey meat (9). S. aureus is common in pork samples; however, its prevalence varies between countries. For instance, in Germany $S$. aureus was detected in $4.2 \%$ of pork samples (3), in Taiwan in 9\% (21), whereas in the USA in $45.6 \%$ of pork samples (25). Contamination of raw meat may result from colonisation of farm animals with S. aureus, particularly the CC398 (8). However, contamination of meat through human handling during processing is also possible (31). The results presented in this paper confirmed the presence of $S$. aureus, including MSSA and MRSA belonging to the CC398 in raw pork and poultry meat and food of animal origin in Poland, which was described previously by others (4, $19,20,24)$. According to our knowledge, this is the first report on the isolation of MSSA belonging to the CC398 from beef. It is significant that despite a small number of beef samples tested, one isolated strain was recognised as S. aureus CC398. Determination of the prevalence of strains from the CC398 among cattle and beef requires further studies.

More than 20 types of staphylococcal enterotoxins (SEs) showing phylogenetic relationship and sequence similarities have been described so far (15). SEs have been traditionally divided into classical (SEA to SEE) and new enterotoxins (SEG, SEH, SEI, SEJ, SEK, SEL, SEM, SEN, SEO, SEP, SER, and SEU) (29). A study conducted in Japan showed that $21.7 \%$ of S. aureus strains obtained from raw meat or food products of animal origin were positive for one or more classical enterotoxin genes (A-E) (17). Recently, isolation of $S$. aureus harbouring new enterotoxin genes from the finished meat products, and also from raw milk and dairy products has been reported with increased frequency $(1,25)$. Pu et al. (25) reported that $85 \%$ of $S$. aureus strains isolated from pork and beef were positive for at least one classical or new enterotoxin genes, and $66 \%$ harboured two or more of these genes. With regard to new STs, SEG and SEI are the most frequently detected and their presence was demonstrated in $66 \%$ of $S$. aureus strains isolated from meat samples in USA $(1,25)$. Moreover, the presence of classical and new staphylococcal enterotoxin genes was demonstrated also among coagulase-negative staphylococci obtained from beef and lamb meat (16) and from milk (24).

The results from Poland presented by Bystron et al. (4) showed that $55 \%$ of $S$. aureus isolated from pigs and pork harboured genes encoding classical enterotoxins and $45 \%$ carried genes encoding new enterotoxins. Similarly to our results, the seg and sei genes were the most prevalent. However, in our study only two isolates were positive for classical enterotoxin genes. In general, enterotoxin genes are not widespread among the MRSA CC398 lineage (12). Some reports described the CC398 strains carrying enterotoxin genes (seb, sed, see, seg, sei, seg, sek, sem, ser) genes (4). European Union Regulation 1441/2007 specifies the detection of SE in food of animal origin, but according to this regulation only the presence of classical enterotoxins is investigated (6). Therefore, the food is currently not examined for the presence of new enterotoxins. Thus, it could be assumed that the true incidence of new enterotoxin genes remains unknown.

PFGE typing is one of the best molecular methods of epidemiological analyses of $S$. aureus. One of the aims of this research was to compare $S$. aureus strains isolated from different meat processing plants. $S$. aureus belonging to the CC398 are nontypeable using SmaI (31) and this was observed in five strains detected in our study. In general, a high similarity was observed among the obtained PFGE profiles. Two MSSA isolates (6/04 and 5/04) recovered from beef and pork in the same plant exhibited $100 \%$ identity in PFGE profiles. Moreover, both of them had the same resistance patterns and were positive for the seg and sei resistant genes, implying that the raw meat could have been contaminated during processing.

In general, LA-MRSA isolates, representing multidrug-resistant phenotype, usually are resistant to all $\beta$-lactams, tetracyclines, macrolides, lincosamides, and streptogramides $(12,31)$. Accordingly, two MRSA CC398, three MSSA CC398, and one MSSA isolates were multidrug-resistant in our study. These results are in accordance with the data obtained in the USA, where multidrug resistance was commonly observed among MRSA as well as $S$. aureus from pork (1, 25). However, the majority of MSSA isolates described in our study were susceptible to all antimicrobials tested or showed only the amoxicillin resistance. The presence of resistant bacteria in food of animal origin is highly undesirable, since resistant genes may be transferred from MRSA to bacteria of the human microbiota.

The study confirms that $S$. aureus strains may adapt to different hosts and are constantly evolving. Łuczak-Kadłubowska et al. (22) showed the presence of different new clones among the population of MRSA in Poland. Therefore, continuous monitoring of the genetic diversity of $S$. aureus, particularly MRSA, is needed. This study presents preliminary data on the characterisation of $S$. aureus obtained from the meat processing plants. Nevertheless, the isolation of MRSA CC398, multidrug-resistant, and enterotoxigenic strains is alarming and further investigations should be undertaken. Extensive studies are necessary to identify the potential sources of contamination of the finished meat products and to establish a potential risk. 
Conflict of Interests Statement: The authors declare that there is no conflict of interests regarding the publication of this article.

Financial Disclosure Statement: The study was financially supported by the Rector of WULS, internal competition mode for participants of the young scientists.

Animal Rights Statement: None required.

\section{References}

1. Abdalrahman L.S., Wells H., Fakhr M.K.: Staphylococcus aureus is more prevalent in retail beef livers than in pork and other beef cuts. Pathogens 2015, 28, 182-198.

2. Becker K., Roth R., Peters G.: Rapid and specific detection of toxigenic Staphylococcus aureus: use of two multiplex PCR enzyme immunoassays for amplification and hybridization of staphylococcal enterotoxin genes, exfoliative toxin genes, and toxic shock syndrome toxin 1 gene. J Clin Microbiol 1998, 36, 2548-2553.

3. Beneke B., Klees S., Strührenberg B., Fetsch A., Kraushaar B., Tenhagen B.A.: Prevalence of methicillin-resistant Staphylococcus aureus in a fresh meat pork production chain. J Food Prot 2011, 74, 126-129.

4. Bystroń J., Podkowik M., Bania J., Krupa P., Schubert J.: Distribution of enterotoxin genes in Staphylococcus aureus isolates from pork and pigs. Med Weter 2015, 71, 341-344.

5. Chen C.J., Huang Y.C.: New epidemiology of Staphylococcus aureus infection in Asia. Clin Microbiol Infect 2014, 20, 605623.

6. Commission Regulation (EC) No. 1441/2007 of 5 December 2007 amending Regulation (EC) No. 2073/2005 on microbiological criteria for foodstuffs. Official J Europ Union, L322, 12-29. https://www.fsai.ie/uploadedFiles/Reg1441_2007 (1).pdf, (accessed 15 June 2016).

7. Cremonesi P., Luzzana M., Brasca M., Morandi S., Lodi R., Vimercati C., Agnellini D., Caramenti G., Moroni P., Castiglioni B.: Development of a multiplex PCR assay for the identification of Staphylococcus aureus enterotoxigenic strains isolated from milk and dairy products. Mol Cell Probes 2005, 19, 299-305.

8. Cuny C., Köck R., Witte W.: Livestock associated MRSA (LAMRSA) and its relevance for humans in Germany. Int $\mathbf{J}$ Med Microbiol 2013, 303, 331-337.

9. de Boer E., Zwartkruis-Nahuis J.T., Wit B., Huijsdens X.W., de Neeling A.J., Bosch T., van Oosterom R.A., Vila A., Heuvelink A.E.: Prevalence of methicillin-resistant Staphylococcus aureus in meat. Int J Food Microbiol 2009, 31, 52-56.

10. European Committee on Antimicrobial Susceptibility Testing (EUCAST): 2015 Breakpoint tables for interpretation of MICs and zone diameters. Version 6.0. http://www.eucast.org (accessed 15 June 2016).

11. European Food Safety Authority (2009) Analysis of the baseline survey on the prevalence of methicillin-resistant Staphylococcus aureus (MRSA) in holdings with breeding pigs, in the EU, Part A: MRSA prevalence estimates. EFSA J 2008, 7, 1376, doi:10.2903/j.efsa.2009.1376.

12. Feßler A.T., Kadlec K., Hassel M., Hauschild T., Eidam C., Ehricht R., Monecke S., Schwarz S.: Characterization of methicillin-resistant Staphylococcus aureus isolates from food and food products of poultry origin in Germany. Appl Environ Microbiol 2011, 77, 7151-7157.

13. Fitzgerald J.R.: Livestock-associated Staphylococcus aureus: origin, evolution and public health threat. Trends Microbiol 2012, 20, 192-198.
14. Ikawaty R., Brouwer E.C., Jansen M.D., van Duijkeren E., Mevius D., Verhoef J., Fluit A.C.: Characterization of Dutch Staphylococcus aureus from bovine mastitis using a Multiple Locus Variable Number Tandem Repeat Analysis. Vet Microbiol 2009, 12, 277-284, doi: 10.1016/j.vetmic.2008.10.034.

15. Kadariya J., Smith T.C., Dipendra Thapaliya D.: Staphylococcus aureus and staphylococcal food-borne disease: an ongoing challenge in public health. Biomed Res Int 2014, http://dx.doi.org/10.1155/2014/827965.

16. Kahya S., Guran H. S., Yilmaz O.: PCR and ELISA for staphylococcal enterotoxins and detection of some exotoxins from Staphylococcus spp. strains by PCR. Med Weter 2016, 72, 28-33.

17. Kitai S., Shimizu A., Kawano J., Sato E., Nakano C., Kitagawa H., Fujio K., Matsumura K., Yasuda R., Inamoto T.: Prevalence and characterization of Staphylococcus aureus and enterotoxigenic Staphylococcus aureus in retail raw chicken meat throughout Japan. J Vet Med Sci 2005, 67, 269-274.

18. Kizerwetter-Świda M., Chrobak-Chmiel D., Rzewuska M., Antosiewicz A., Dolka B., Ledwoń A., Czujkowska A., Binek M.: Genetic characterization of coagulase-positive staphylococci isolated from healthy pigeons. Pol J Vet Sci 2015, 18, 627-634.

19. Krupa P., Bystroń J., Bania J., Podkowik M., Empel J., Mroczkowska A.: Genotypes and oxacillin resistance of Staphylococcus aureus from chicken and chicken meat in Poland. Poult Sci 2014, 93, 3179-3186.

20. Krupa P., Bystroń J., Podkowik M., Empel J., Mroczkowska A., Bania J.: Population structure and oxacillin resistance of Staphylococcus aureus from pigs and pork meat in south-west of Poland. Biomed Res Int 2015, http://dx.doi.org/10.1155/2015/ 141475.

21. Lin J., Yeh K.S., Liu H.T., Lin J.H.: Staphylococcus aureus isolated from pork and chicken carcasses in Taiwan: prevalence and antimicrobial susceptibility. J Food Prot 2009, 72, 608-611.

22. Łuczak-Kadłubowska A., Sulikowska A., Empel J., Piasecka A., Orczykowska M., Kozinska A., Hryniewicz W.: Countrywide molecular survey of methicillin-resistant Staphylococcus aureus strains in Poland. J Clin Microbiol 2008, 46, 2930-2937.

23. Murchan S., Kaufmann M.E., Deplano A., de Ryck R., Struelens M., Zinn C.E., Fussing V., Salmenlinna S., Vuopio-Varkila J., El Solh N., Cuny C., Witte W., Tassios P.T., Legakis N., van Leeuwen W., van Belkum A., Vindel A., Laconcha I., Garaizar J., Haeggman S., Olsson-Liljequist B., Ransjo U., Coombes G., Cookson B.: Harmonization of pulsed-field gel electrophoresis protocols for epidemiological typing of strains of methicillin-resistant Staphylococcus aureus: a single approach developed by consensus in 10 European laboratories and its application for tracing the spread of related strains. J Clin Microbiol 2003, 41, 1574-1585.

24. Piechota M., Kot B., Zdunek E., Mitrus J., Wicha J., Wolska M.K., Sachanowicz K.: Distribution of classical enterotoxin genes in staphylococci from milk of cows with- and without mastitis and the cowshed environment. Pol J Vet Sci 2014, 17, 407-411.

25. Pu S., Wang F., Ge B.: Characterization of toxin genes and antimicrobial susceptibility of Staphylococcus aureus isolates from Louisiana retail meats. Foodborne Pathog Dis 2011, 8, 299-306.

26. Sasaki T., Tsubakishita S., Tanaka Y., Sakusabe A., Ohtsuka M., Hirotaki S., Kawakami T., Fukata T., Hiramatsu K.: MultiplexPCR method for species identification of coagulase-positive staphylococci. J Clin Microbiol 2010, 48, 765-769.

27. Smith T.C., Wardyn S.E.: Human infections with Staphylococcus aureus CC398. Curr Environ Health Rep 2015, 2, 41-51.

28. Stegger M., Lindsay J.A., Moodley A., Skov R., Broens E.M., Guardabassi L.: Rapid PCR detection of Staphylococcus aureus clonal complex 398 by targeting the restriction-modification system carrying sau1-hsdS1. J Clin Microbiol 2011, 49, 732734. 
29. Stryjewski M.E., Corey G.R.: Methicillin-resistant Staphylococcus aureus: an evolving pathogen. Clin Infect Dis 2014, 58, S10-S19. doi: 10.1093/cid/cit613.

30. Tenover F., Arbeit, R.D., Goering R.V., Mickelsen P.A., Murray B.E., Persing D.H., Swaminathan B.: Interpreting chromosomal DNA restriction patterns produced by pulsed-field gel electrophoresis: criteria for bacterial strain typing. J Clin Microbiol 1995, 33, 2233-2239.

31. Verkade E., Kluytmans J.: Livestock-associated Staphylococcus aureus CC398: animal reservoirs and human infections. Infect Genet Evol 2014, 21, 523-530. 